\title{
82. Batostomella (Geinitzella) from South China and Manchuria*.
}

\author{
By Hisakatsu YaBe and Toshio Sugryama. \\ (Comm. by H. YABE, M.I.A., July 13, 1942.)
}

In the "Salt Range Fossils, Coelenterata," 1886", W. Waagen and J. Wentzel founded the genus Geinitzella on Stenopora columnaris (Schlotheim) from Europe and India, while describing
Geinitzella columnaris var. incrustans (Geinitz)
G. $\quad$ c. var. ramosa (Geinitz) multigemmata W. \& W.
G. $\quad$ c. var. ramosa (Geinitz) sparsigemmata W. \& W.
G. $\quad$ c. var. tuberosa (Geinitz)
G. $\quad$ crassa (Lonsdale)

Excluding G. c. tuberosa, all the others were represented in their Salt Range material.

We have numerous records from Europe and Asia of the occurrence of G. columnaris and G. crassa, the former in the Permian and the latter in the Permian as well as in the Upper Carboniferous ${ }^{2}$. Seeing, however, that in most cases the remains are neither fully described nor figured with accuracy, in the present study we were obliged to rely almost solely upon Waagen and Wentzel's work cited above, in which the two species are adequately characterized.

The first generic diagnosis by Waagen and Wentzel of Geinitzella, then assigned to the Coelenterata, reads :-

"Corallum creeping or arborescent, composed of more or less cylindrical corallites which augment by intermural gemmation or fissiparity and are transversely wrinkled. The walls of the corallites in arborescent forms are strongly thickened in the peripheral parts. The thickening of primordial wall preceding gemmation project from the surface of the colonies as little spines, which surround the apertures of the corallites. Tabulae very rare or nearly absent." follows :

As a genus of Bryozoa, Geinitzella was defined by C. Diener ${ }^{3)}$ as

„Die vielgestaltigen Kolonien der Geinitzellen sind bald kriechend, bald baumförmig verzweigt. Grenzen zwischen den einzelnen Zellen stetz durch scharfe Trennungslinien deutlich bestimmt. Die Zellen selbst sind zylindrisch und in der peripherischen Region stark verdickt. Zwischen den normalen Zellen schalten sich unregelmässig verteilte Zwischenzellen (Mesoporen) ein. In der Umgebung der Zellmündungen ragen gelegentlich stumpfe Dornen in Verbindung mit zylindrischen Röhrchen (Acanthoporen) über die Oberfläche empor. Böden sehr selten oder ganz fehlend. Fortpflanzung teils durch Knospung innerhalb der Zellwände, teils durch Teilung.“ Academy.

* One of the researches done in 1942 with the aid of a grant from the Imperial

1) Palaeontologia Indica, Ser. XIII, Salt-Range Fossils, I, Productus limestone Fossils, 6, Coelenterata, 1886, p. 891.

2) R.S. Bassler: Bryozoa. Fossilium Catalogus, 1, Animalia, Pars 67, 1934, p. 54.

3) C. Diener: Leitfossilien des marinen Perm. G. Gürich: Leitfossilien, Lf. V, 1927, p. 16. 
There is some confusion regarding the application of the generic name Geinitzella; R.S. Bassler ${ }^{1)}$ and other American writers agree in taking for its genolectotype the ramose form, G. columnaris (G. c. var. ramosa of Waagen and Wentzel). Its structure was described in detail and elaborately figured by Waagen and Wentzel in their work, while G. W. Lee ${ }^{2)}$ selected G. $c$. var. incrustans, the first of the two authors's varieties, in order of description, which, however, according to Bassler" "seems to be the incrusting portion of a Batostomella without diaphragms."

Geinitzella closely resembles Batostomella Ulrich, the prevailing view at present being that the two are generically indistinguishable. Bassler, notwithstanding that he held that the two were generically identical, distinguished two groups in Batostomella, separating Geinitzella apparently with no diaphragms from Batostomella, s. s. with a few diaphragms $\mathrm{s}^{4}$.

The genotype of Batostomella is B. spinulosa Ulrich from the Lower Carboniferous of Kentucky, U. S. A., its generic diagnosis ${ }^{5)}$ being

"Slender branches, with thick-walled zooecia, few diaphragms, and small circular or oval apertures with rounded or canaliculate interspaces; numerous small acanthopores, and mesopores, the latter with subcircular opening."

Bassler $^{6)}$ wrote :

"This interesting genus which exhibits the thick fused walls characteristic of the family" (Batostomellidae) "in great perfection, may be distinguished from related genera by its ramose zoarium in which the zooecia develope a few diaphragms and few to numerous subcircular mesopores with the walls of the tubes without periodic swellings. Acanthopores are usually very numerous and conspicuous."

Batostomella is the representative genus of the family Batostomellidae, which is included in the suborder Amalgamata of O. E. Ulrich and Bassler. This suborder, together with the other, Integrata, constitutes the order Trepostomata. The Amalgamata, as also the genus Batostomella, are characterized by completely fused walls of adjacent zooecia in the mature region. In his paper on the Permian Bryozoa of Timor"), Bassler writes "the middle zone clearer than the edges (left by fusion) of walls in mature region, for the characterization of the family ; this no doubt corresponds to the "canaliculate interspaces" of Ulrich in his generic diagnosis of Batostomella, quoted above, and also to the "primordial wall" of Waagen and Wentzel, on which they laid great stress in their description of the microstructure of the walls of Geinitzella from the Salt Range.

1) R.S. Bassler: The Permian Brybzoa of Timor. Palaeontologie von Timor, Lf. XVI, 1929, p. 61.

2) G. W. Lee: The British Carboniferous Trepostomata. Mem. Geol. Surv. Great Britain, Palaeontology, Vol. I, Pt. 3, 1912, p. 152.

3) R.S. Bassler: 1934, l. c., p. 114. In his report on Timor bryozoa, the same author stated G. columnaris incrustans to be a Dyacritella.

4) R. S. Bassler: 1929, 1. c., p. 55.

5). J. M. Nickles and R.S. Bassler: A Synopsis of American Fossil Bryozoa. U.S. Geol. Surv. Bull. No. 173, 1900, p. 32 (cited after G. W. Lee, l. c.).

6) R.S. Bassler: 1929 , l. c., p. 60.

7) R. S. Bassler: 1929 , 1. c., p. 54. 
The zooecia in G. columnaris and G. crassa, figured by Waagen and Wentzel, are almost free from tabulae or diaphragms. According to the authors' generic diagnosis "Tabulae yery rare or nearly absent." Later Bassler" wrote- " the presence of a few diaphragms in Batostomella and their apparent absence in Geinitzella may make it advisable sometime to separate the two groups."

Now the question arises, are there a few diaphragms in the zooecia of Geinitzella, or are there none? Describing Geinitzella chinensis from China, G. H. Girty ${ }^{2)}$ noted that diaphragms occur in his new species, which resembles the Salt Range species, and that they are likely to be found also in the latter. From the present study we get also the same impression, seeing that our forms from South China and Manchuria, to be described now, likewise possess diaphragms, although in one of the specimens, they nearly escaped our notice. Even should Geinitzella, on account of its lacking diaphragms, form a group distinct from Batostomella, s. s., there is still no doubt about the Batostomella-like nature of the fossils at our disposal, owing to their possessing a fair number of well developed diaphragms. It may further be said in this connection that, most, if not all, the species that are usually assigned to Geinitzella have large zoaria, much more so than those of the typical species of Batostomella, and also that, while the latter are very common in Gotlandian-Permian formations, broader forms are almost confined to the uppermost Carboniferous and Permian rocks.

A quarter century ago, one of us (Yabe) had an opportunity to study with the aid of Mr. I. Hayasaka, some fossils collected by the late Professor K. Yamada from South China, of which two were believed to belong to the genus Geinitzella. These were figured without description under the $G$. crassa, in the "Geographical Research in China, 1911-16, Atlas of Fossils," edited by the Tokyo Geographical Society, in 1920, Pl. VII, Figs. $1 \mathrm{a}, \mathrm{b}, 2 \mathrm{a}, \mathrm{c}$. One of them (Figs. $1 \mathrm{a}, \mathrm{b}$ ) is from Chihai, Tonchwän, in Yunnan ${ }^{3)}$ and the other (Figs. 2 a, c) from Kiangti, Lutien-hsien ${ }^{4}$, in the same province. The latter was erroneously stated in the explanation of Plate VII, as having been derived from the same locality as that of the former. Re-examination of thin sections of these specimens has shown them to be two distinct species.

G. crassa from Lunan ${ }^{5)}$ in Yunnan and Takreem in Cambodia were illustrated by $H$. Mansuy in 1912 and 1913 respectively ${ }^{6}$. The specimen from Lunan is a broad cylindrical zoarium, more than $20 \mathrm{~mm}$ broad,

1) R.S. Bassler: 1929, 1.c., p. 55 .

2) G. H. Girty: A Report on Upper Paleozoic Fossils collected in China in 1903-04. Research in China edited by Carnegie Institution of Washington, 1913, p. 315, pl. XXVIII, figs. 9-14.

3）雲南省東川縣者海.

4) 雲南省魯甸縣江底.

5) 路南.

6) H. Mansuy: Étude géologique du Yun-nan oriental, II, Paleontologie. Mém. Serv. Géol. Indochine, Vol. I, Fasc. II, 1912, p. 114, Pl. XXI, figs. 1 a, b. Faunes des calcaires a Productus de l'Indochine, I Ser. Ibid., Vol. II, Fasc. IV, 1913, p. 113, Pl. XII, figs. $3 \mathrm{a}-\mathrm{d}$. 
thus greatly exceeding in size any other form previously recorded from various places under the same specific name, but equal to the Kiangti specimen now at our disposal. Unfortunately, the microscopical details of the inner structure of the former are not known, making it impossible to verify its specific identity with the latter which, however, seems very probable owing to the similar size of zoarium and zooecia, and because of the proximity of the two localities. The Lunan specimen is derived from a limestone, together with brachiopods of the Lower and Middle Permian habits, and correlated by Mansuy with the Upper Productus limestone of the Salt Range.

In the specimen from Chihai, the zoarium is narrower than that from Kiangti, being almost similar in size to those of G. crassa from the Salt Range; its zooecia, besides, having more numerous diaphragms, often on common levels, which condition we do not find in the Kiangti specimen.

Another specimen dealt with in this article was forwarded with some other Permian fossils by Mr. Ikunosuke Nozaki, manager of the Zyoran (Shulan) $)^{1)}$ Colliery of Manchoukuo to Mr. S. Endo of our Institute of Geology and Palaeontology, Tôhoku Imperial University, who placed them at our disposal for study. These fossils are from an impure limestone exposed some $10 \mathrm{~km}$ north-east of the railway station, Shanhotun ${ }^{2}$, on the Kiaoho ${ }^{3}$-Harbin line; the locality lies close to the Zyoran coalfield. This specimen, with its numerous thick acanthopores, reminds us of G. crassa from Takreem which possesses numerous, prominent acanthopores, as may be seen from the figures (Pl. XII, Figs. $3 \mathrm{a}$ and $\mathrm{c})$ with the aid of a magnifier; however, in the latter, the zoarium is much more slender and the zooecia are also decidedly narrower.

G. crassa has also been reported from Mongolia and from near V.ladivostock, as also another species, G. chinensis Girty,. from Taninghsien, eastern Szechuan, China. None of the specimens from the Jisu Honguer limestone of Mongolia as figured by A. W. Grabau ${ }^{4)}$ seems to belong to this species, while neither description nor figure of the specimens from near Vladivostock is accessible to us to enable confirmation of the specific identification ${ }^{5}$. As to G. chinensis from Szechuan ${ }^{6}$, it is a very peculiar species, having monilated walls in that part of the zoarium that is transitional from the axial part to the peripheral.

1) 舒蘭.

2) 山河屯.

3) 蛟河.

4) A. W. Grabau: The Permian of Mongolia. A Report on the Permian Fauna of the Jisu Honguer Limestone of Mongolia and Its Relations to the Permian of Other Parts of the World. Natural History of Central Asia, edited by the American Museum of Natural History, Vol. IV, 1931, p. 46, Pl. I, figs. $10 \mathrm{a}, \mathrm{b}, 11 \mathrm{a}, \mathrm{b}, 12 \mathrm{a}, \mathrm{b}$.

5) P. Wittenbourg: La description géologique de la presqu'ile de MouravievAmourski et de l'Archipel de l'Impératrice Eugénie. Mém. Soc. Études de la Region de l'Amour, Vol. XV, 1916, pp. 182, 372.

6) G. H. Girty: 1.c. 
Description.

Batostomella (Geinitzella) hayasakai, sp. nov.

Figs. $1 \mathrm{a}, \mathrm{b}$.

1920. Geinitzella crassa, in Geographical Research in China, edited by the Tokyo Geographical Society, Atlas of Fossils, Pl. VII, Figs. 2 a, c.

A fragmental zoarium, columnar, almost round or somewhat oblong in cross-section, $25 \mathrm{~mm}$ in longer diameter, with zooecia longitudinally disposed in axial part and normal to the surface in the peripheral, their rather abrupt turning in growth-direction being shown by relatively narrow transitional zone, the average breadth of peripheral zone some $1 / 3$ the diameter of zoarium. In tangential section near the surface of zoarium, zooecia round or rounded polygonal, zooecial hollows $0.15-$ $0.25 \mathrm{~mm}$ broad, separated by much thickened walls which are usually broader than $0.05 \mathrm{~mm}$ and traversed by rather numerous mesopores and acanthopores ; mesopores mostly roundish, but not seldom tri-tetralobed, $0.1-0.2 \mathrm{~mm}$ broad in round ones; acanthopores in two different sizes, slender ones $0.03-0.06 \mathrm{~mm}$ broad, round in outline, broader ones often almost equal in size and outline to and only differing by being compact instead of hollow, from mesopores. In cross-section of zoarium, zooecia of axial part tetra-hexagonal in outline, and wide spaced, owing to thin straight walls; those of peripheral zone showing distant, very thin, complete, horizontal diaphragms which are sometimes hardly discernible as such under the microscope unless favourably illuminated. Surface feature unknown, probably provided with a few monticules, judged on the rare occurrence of clusters of larger zooecia than usual ones in tangential section of zoarium.

Remarks: In its general features and structural details, this species is similar to Geinitzella crassa, from the Salt Range described by Waagen and Wentzel, differing from it only in possessing distant diaphragms that are very thin, but fairly distinct, and more markedly acanthopores in two different sizes. In the size of zoarium and zooecia, our species is almost indistinguishable from " $G$. crassa" of Mansuy from Lunan in Yunnan, the structural details of which, however, are unfortunately not known. Nevertheless, the specific identity of the two is suspected from the nearness of their respective localities, as already mentioned. Reg. No. 6275 .

Locality: Kiangti, Lutien-hsien, Yunnan; collected by K. Yamada' Geological age: Probably Lower Permian.

Batostomella (Geinitzella) yunnanensis, sp. nov.

Figs. $2 \mathrm{a}-\mathrm{b}$.

1920. Geinitzella crassa in Geographical Research in China, edited by the Tokyo Geographical Society, Atlas of Fossils, Pl. VII, Figs. 1 a, b.

A fragment of dark coloured limestone with three zoaria, which

1) K. Yamada: Diary of the Journey through the Region of the Upper Course of the Yangtzekiang (in Japanese), posthumous edition, 1930, p. 99, Atlas, Sheet 33. 
are columnar, round in cross-section, and $14 \mathrm{~mm}$ broad, being narrower than the preceding species. Zooecia arranged as in the preceding species, but with relatively narrower peripheral zone, with breadth about $1 / 7$ the diameter of zoarium. In tangential section of zoarium, zooecial hollows $0.2-0.25 \mathrm{~mm}$ broad, rounded polygonal, separated by thinckened walls which are usually $0.05-0.15 \mathrm{~mm}$ broad ; besides, larger zoaria with irregular or more or less indented outline evenly disseminated among the others, probably indicating the minutely, but densely monticulated, surface of zoarium; mesopores less numerous and more polygonal than in the preceding species, less than $2 \mathrm{~mm}$ in diameter; acanthopores of one kind only, up to $0.1 \mathrm{~mm}$ broad, generally round in outline; rarely somewhat elongated, most of them lying at the junction of walls, and also frequently protruding into zooecial hollows. In cross-section of zoarium, zooecia show many complete horizontal diaphragms, 5-6 counted in $2 \mathrm{~mm}$, and often arranged on common levels.

Remarks: This species more closely approaches $G$. crassa from the Salt Range than the preceding species in the size of zoarium and several features of zooecia, mesopores, and acanthopores; but its zooecia possess more numerous and distinct diaphragms, generally arranged on common levels. Reg. No. 6256.

Locality : Chihai, Tonchwan, in Yunnan.

Geological age: Probably Lower Permian.

Batostomella (Geinitzella) manchuriensis, sp. nov.

Figs. $3 \mathrm{a}, \mathrm{b}, 4 \mathrm{a}-\mathrm{c}$.

Fragmental zoarium, which is columnar, over $35 \mathrm{~mm}$ long and somewhat oblong in cross-section $(16 \times 13 \mathrm{~mm})$, with zooecia disposed longitudinally in axial part and radially in the peripheral. In tangential section near the surface of zoarium, zooecia round or rounded polygonal, zooecial hollows $0.2-0.3 \mathrm{~mm}$ broad, being broader than in the two preceding species and separated by thickened walls more than $0.05 \mathrm{~mm}$ in breadth and traversed by numerous mesopores and acanthopores; mesopores fewer than in $G$. hayasakai; acanthopores of one kind only, prominent, being broader than the slender ones in $G$. hayasakai. In cross-section of zoarium, zooecia of axial part tri-hexagonal in outline, wide-spaced and bordered by duplicate walls, having a distinct median dark line, and minute, but distinct, round acanthopores at their junction; zooecia of peripheral part in longitudinal section trasversed by distant complete diaphragms and separated by duplicate walls, having a distinct median dark line which disappears on approaching the surface of zoarium. Surface feature unknown.

Remarks: In the size of zoarium, this species is close to $G$. chinensis Girty, from Szechuan, China, but the two differ entirely in their detail structure. Our form resembles " $G$. crassa" from Takreem, Cambodia, in having prominent acanthopores; but the zoarium of the latter is not only somewhat slender, but also has smaller zooecia. The walls in the present species are distinctly duplicate for almost the entire length of zooecia; notwithstanding this peculiarity, it is temporarily 


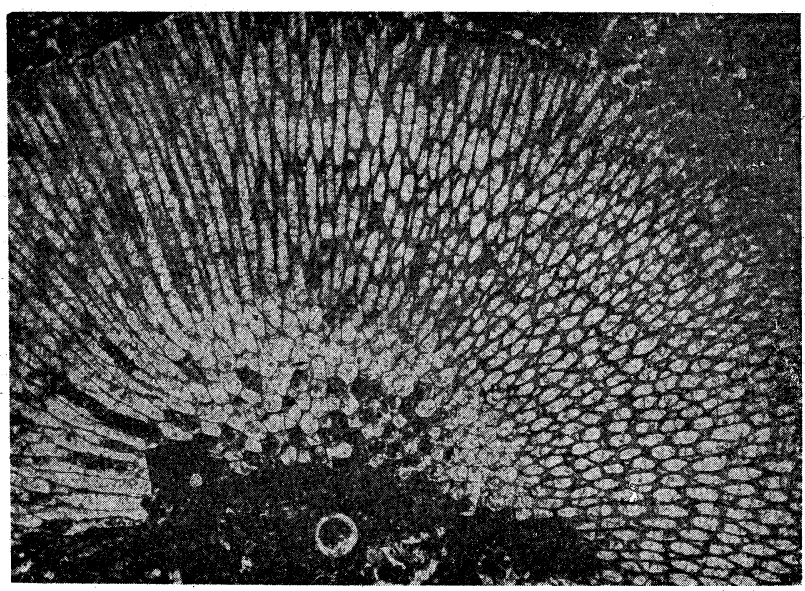

$1 \mathrm{a}$

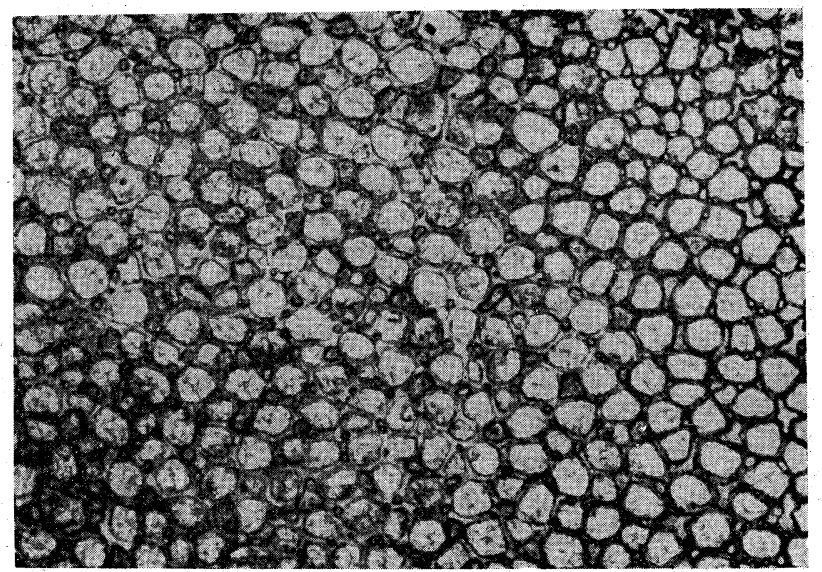

$1 \mathrm{~b}$

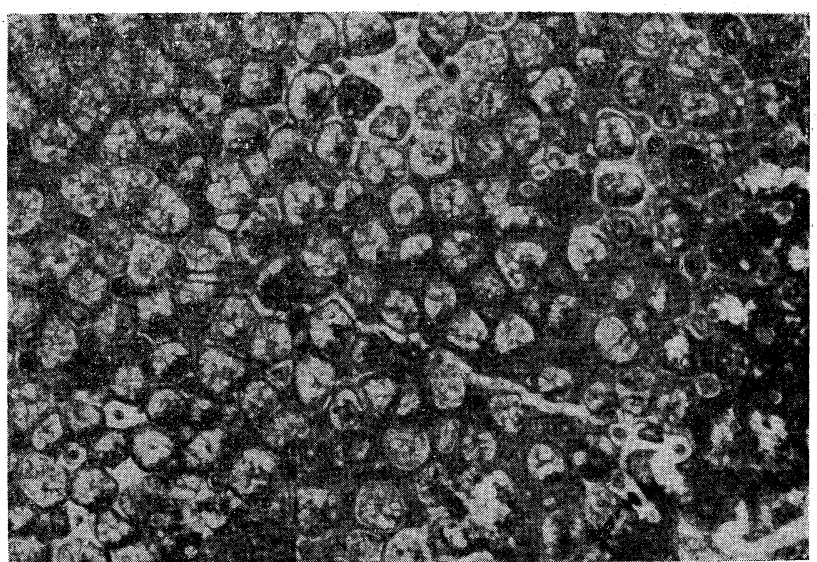



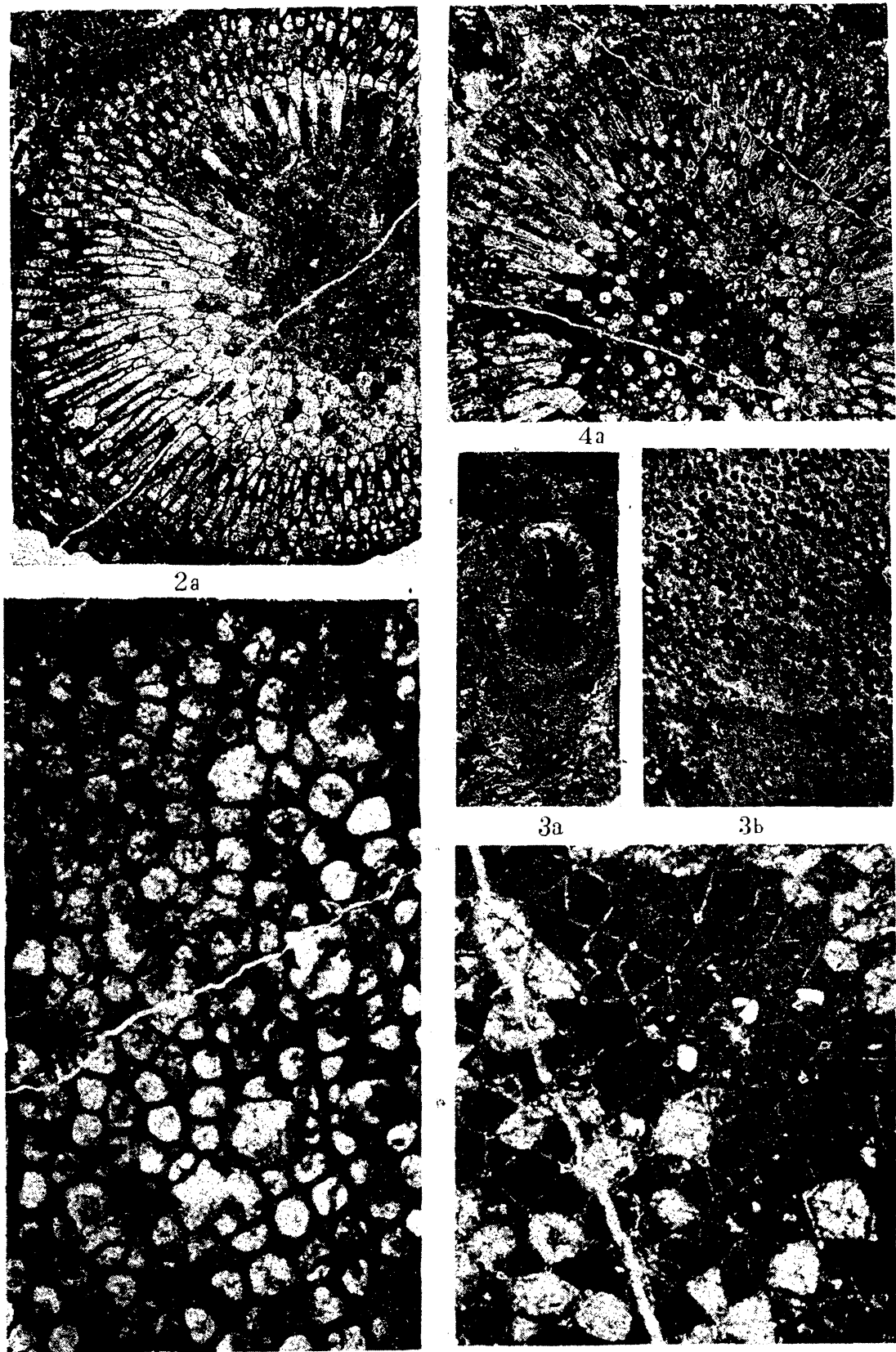

$2 b$

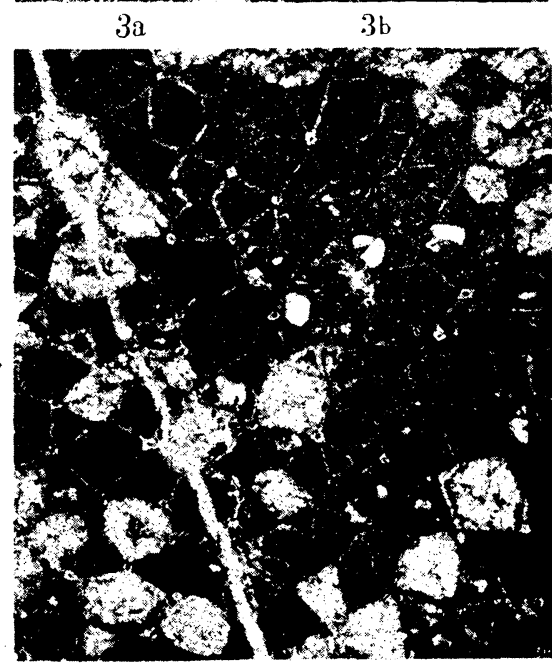

$4 \mathrm{c}$

Fig. 1. Batostomella (Geinitzella) hayasakai, sp. nov. a, zoarium in crosssection, ca. $\times 5 ;$ b, in tangential section near the surface, ca. $\times 15$.

Fig. 2. Batostomella (Geinitzella) yunnanensis, sp. nov. a, zoarium in crosssection, ca. $\times 5$; b, in tangential section near the surface, ca. $\times 15$.

Fig. 3. Batostomella (Geinitzella) manchuriensis, sp. nov. a, weathered surface, nat. size; b, surface of zoarium, ca. $\dot{x} 5$.

Fig. 4. Batostomella (Geinitzella) manchuriensis, sp. nov. a, zoarium in cross-section, ca. $\times 5$; b, in tangential section near the surface, ca. $\times 15$; , axial part, ca. $\times 15$. 
assigned to Batostomella (Geinitzella), since in all other features it is built quite similar to the two preceding species. Reg. No. 65298.

Locality : $10 \mathrm{~km}$ north-east of the railway station, Shanhotun, on the Kiaoho-Harbin line, the locality lying close to the Zyoran coalfield; found in an impure limestone.

Geological age: Lower Permian.

Finally our thanks are due to Mr. Nozaki, of the Zyoran Colliery, for contribution of the material. 